\title{
EFEKTIFITAS MIKROORGANISME LOKAL (MOL) LIMBAH BUAH-BUAHAN SEBAGAI AKTIFATOR PEMBUATAN KOMPOS
}

\author{
Haidina Ali \\ Politeknik Kesehatan Kementerian Kesehatan Bengkulu, Jurusan Kesehatan Lingkungan, \\ Jalan Indragiri Nomor 03 Padang Harapan Kota Bengkulu \\ Alie_7@ymail.com
}

\begin{abstract}
Constraints or public complaints in the process of composting organic waste lies in the composting process that takes a long time between 2-3 months and acceptance of people who are less fit to existing activator as EM4 scarce in Rural. The purpose of this study was to determine the effectiveness of the Local Microorganisms activator (MOL) waste fruits of the length of time the formation of compost organic waste. This type of research is an experimental design using "posttest with control". The results of the study the average length of time (days) composting organic waste with the addition of MOL activator dose of $10 \mathrm{~mL}$ for 24 days, a dose of $15 \mathrm{ml}$ for 18.6 days, a dose of $20 \mathrm{~mL}$ for 15 days, and a dose of $25 \mathrm{ml}$ for 11.6 days. The addition of MOL activator with a dose of 25 $\mathrm{mL}$ is the most effective dose in composting organic waste. Obtained $\mathrm{p}=0.000<\alpha=0.05$; there were significant differences between the old time of the formation of the addition of compost activator Local Microorganisms (MOL) at a dose of activator $10 \mathrm{~mL}, 15 \mathrm{~mL}, 20$ $\mathrm{mL}$ and $25 \mathrm{~mL}$. Expected research MOL activator use in composting organic waste can be a solution, especially for people in overcoming the problem of composting which takes a long time.
\end{abstract}

Keywords: Compost, Local Microorganisms (MOL), activator, Bengkulu City

\begin{abstract}
Abstrak : Kendala atau keluhan masyarakat dalam proses pengomposan sampah organik terletak pada proses pengomposan yang memerlukan waktu lama antara 2-3 bulan dan penerimaan masyarakat yang kurang pas terhadap aktivator yang sudah ada seperti $\mathrm{EM}_{4}$ yang sulit didapat di Pedesaan. Tujuan dilakukan penelitian ini adalah untuk mengetahui efektifitas aktivator Mikroorganisme Lokal (MOL) limbah buah-buahan terhadap lama waktu terbentuknya kompos sampah organik. Jenis penelitian yang ini merupakan eksperimen dengan menggunakan desain "posttest with control". Hasil penelitian rerata lama waktu (hari) pembentukan kompos sampah organik dengan penambahan aktivator MOL dosis $10 \mathrm{~mL}$ selama 24 hari, dosis $15 \mathrm{~mL}$ selama 18,6 hari, dosis $20 \mathrm{~mL}$ selama 15 hari, dan dosis $25 \mathrm{~mL}$ selama 11,6 hari. Penambahan aktifator MOL dengan dosis $25 \mathrm{~mL}$ merupakan dosis yang paling efektif dalam pembentukan kompos sampah organik. Didapatkan $\mathrm{p}=0,000<\alpha=0,05$; ada perbedaan bermakna antara lama waktu terbentuknya kompos terhadap penambahan aktivator Mikroorganisme Lokal (MOL) dengan dosis aktivator $10 \mathrm{~mL}, 15 \mathrm{~mL}, 20 \mathrm{~mL}$, dan $25 \mathrm{~mL}$. Diharapkan penelitian penggunaan aktifator MOL dalam pembuatan kompos sampah organik ini dapat menjadi sebuah solusi khususnya bagi masyarakat dalam mengatasi masalah pengomposan yang memerlukan waktu lama menjadi lebih cepat.
\end{abstract}

Kata Kunci : Kompos, Mikroorganisme Lokal (MOL), Aktivator, Kota Bengkulu

Derajat kesehatan dan kualitas hidup manusia bergantung kepada kemampuan untuk menyikapi, mengelola hubungan timbal balik antara aktifitas manusia dengan lingkungan fisik dan biologinya. Di muka bumi tidak ada satupun yang berdiri sendiri, semuanya saling bergantung dan saling membutuhkan satu dengan yang lain. Oleh karena itu, diperlukan adanya wawasan mengenai Lingkungan, Ilmu Pengetahuan dan Teknologi (IPTEK) yang akan mengarah pada pemeliharaan dan pelestarian lingkungan hidup (L. Blumm, 2007) 
Pemeliharaan dan pelestarian lingkungan hidup tidak lepas dari beberapa masalah, contohnya masalah kesehatan lingkungan yang diakibatkan oleh aktifitas manusia dalam mencapai kesejahteraannya adalah timbulnya bahan buangan yang sudah tidak dipakai dan tidak diinginkan lagi yang disebut dengan sampah.

Terlepas dari wujudnya secara umum, sampah dapat dibedakan menjadi dua kategori yaitu : sampah industri dan sampah umum. Sampah industri adalah sampahsampah yang dihasilkan dari kegiatan produksi. Sampah industri juga dibedakan lagi menjadi dua jenis yaitu : sampah industri terkontrol khusus dan sampah industri lainnya, termasuk didalamnya limbah industri. Sementara, semua sampah di luar kategori sampah industri disebut sampah-sampah umum, dan secara garis besar dibagi menjadi tiga yaitu : sampah umum terkontrol khusus, limbah umum dan tinja, dan sampah umum lainnya atau lebih dikenal dengan nama Municipal Solid Waste (Wardhani, 2007).

Faktor yang mempengaruhi timbunan sampah perkotaan di suatu Negara tidak terlepas dari tiga faktor yaitu : tingkat konsumsi, tingkat pendapatan, dan kepadatan penduduk di perkotaan. Tingkat konsumsi masyarakat sangat mempengaruhi timbunan sampah pada suatu wilayah atau Negara. Pola hidup konsumtif yang digambarkan dalam tingginya tingkat konsumsi, mendorong orang tidak hanya memenuhi kebutuhan primer, namun juga mengejar kebutuhan sekunder, dan kebutuhan tersiernya. Hal ini akan menentukan jenis dan jumlah sampah yang dihasilkan oleh individu setiap hari. Dapat disimpulkan bahwa pada zaman yang modern ini, sampah yang dihasilkan semakin hari semakin bervariasi jenis dan bertambah jumlahnya (Wardhani 2007).

Masalah sampah merupakan masalah yang umum dan telah menjadi fenomena universal di berbagai belahan dunia manapun, dengan titik perbedaanya terletak pada seberapa banyak sampah yang dihasilkan. Setiap orang diperkirakan menghasilkan sampah organik secara langsung maupun tidak langsung sekitar $1 / 2 \mathrm{~kg}$ setiap harinya.

Jumlah penduduk Indonesia pada tahun 2012 sebanyak 257.516.167, maka produk sampah perhari 128.758.083.500 ton (Badan Pusat Statistik, 2012). Jumlah penduduk provinsi Bengkulu tahun 2011 sebanyak 1.715.518 jiwa, maka produksi sampah perhari sebanyak 857.759.000 ton. Pengolahan sampah di Kota Bengkulu sebagian dikelola oleh Dinas Kebersihan dan Pertamanan Kota Bengkulu, selebihnya dikelola secara swakelola oleh masyarakat dengan cara ditimbun dan dibakar. Jumlah penduduk Kota Bengkulu pada tahun 2011 sebanyak 313.324 jiwa menghasilkan 156.662.000 ton/hari, namun Kota Bengkulu baru dapat mengelola sampah sebanyak $1.326 \mathrm{~m}^{3}$ sampah. Tingginya angka pengumpulan sampah khususnya di Kota Bengkulu sehingga diperlukan suatu alternatif untuk mengatasi tingginya timbunan sampah tersebut, salah satunya dengan cara pengomposan untuk jenis sampah organik.

Hal ini sesuai dengan Undang-Undang Nomor 18 Tahun 2008 dinyatakan bahwa pengolahan sampah rumah tangga dan sampah sejenisnya yang terdiri dari pengurangan sampah. Pemanfaatan sampah dengan pengomposan merupakan cara dalam menangani sampah yang dihasilkan dari kegiatan masyarakat yang sebagian besar sampah organik. Kendala atau keluhan masyarakat dalam sistem pengomposan sampah organik terletak pada proses pengomposan yang memerlukan waktu lama antara 2-3 bulan dan penerimaan masyarakat yang kurang pas terhadap aktifator yang sudah ada seperti EM4 yang sulit didapat di pedesaan.

Dampak buruk akibat sampah bagi kesehatan manusia akibat tidak mendapatkan pengolahan akan menyebabkan berbagai penyakit seperti kecacingan, diare, gatal-gatal pada kulit. Selain itu, lama waktu pengomposan yang tidak tertangani dengan baik dapat dirasakan oleh seluruh lapisan masyarakat yang berada disekitar tempat tersebut, karena dampak yang ditimbulkan dapat tersebar dengan cepat apabila kondisi 
lingkungan buruk sehingga masyarakat mudah diserang penyakit bawaan sampah. Oleh karena itu, perlu dicari alternatif pemecah masalah dengan cara menemukan suatu bahan yang berfungsi sebagai aktifator dalam pengomposan sehingga dapat mempercepat waktu pengomposan. Bahan aktifator tersebut antara lain adalah limbah buahbuahan antara seperti buah pisang, mangga, pepaya, dan apel yang kemudian disebut Mikroorganisme Lokal (MOL) (Nurhayati, 2012).

Pemanfaatan MOL sebagai komponen dalam pupuk mikroba diharapkan mampu membantu petani dalam produksi pupuk dan pestisida organik. Petani diharapkan mau dan mampu memanfaatkan mikroba-mikroba lokal yang hidup di sekitar kita. Dengan adanya temuan aktifator ini sehingga pemanfaatan sampah organik dapat dioptimalkan tanpa ada kendala.

Berdasarkan uraian diatas, maka tujuan penelitian ini adalah untuk mengetahui efektifitas aktivator Mikroorganisme Lokal (MOL) limbah buah-buahan terhadap lama waktu terbentuknya kompos sampah organik.

\section{BAHAN DAN CARA KERJA}

Penelitian ini merupakan penelitian eksperimen dengan rancangan post test with control desain. Bahan yang digunakan dalam penelitian ini terdiri dari 2 kelompok. Kelompok pertama yaitu bahan untuk pembuatan aktifator mikroorganisme lokal (MOL) yaitu buah-buahan sebanyak $4 \mathrm{Kg}$, terasi udang 200 gram, gula 5 gram dan air $1200 \mathrm{ml}$. kelompok kedua yaitu bahan untuk membuat kompos terdiri dari sayuran hijau 8 $\mathrm{kg}$, daun krinyu $8 \mathrm{~kg}$, dan batang pisang 8 $\mathrm{kg}$. aktivator mikroorganisme lokal (MOL) dibuat dengan cara memfermentasikan seluruh bahan yang dimasukkan dalam botol ukuran $1500 \mathrm{ml}$ selama 4 hari, setelah 4 hari maka aktivator telah bisa digunakan sebagai aktivator pengomposan. Sedangkan untuk pembuatan kompos semua bahan harus dirajang terlebih dahulu dengan ukuran 2-5 $\mathrm{cm}$ lalu dimasukkan dalam digester berupa polybag dan ditambahkan aktifator MOL dengan dosis $10 \mathrm{ml}, 15 \mathrm{ml}, 20 \mathrm{ml}$, dan 25 $\mathrm{ml}$. Analisis data dilakukan secara deskriptif yang disajikan dalam bentuk tabel dan analisis bivariat untuk melihat pengaruh yang paling efektif dalam proses pembentuk kan kompos.

\section{HASIL}

Data yang diperoleh dari hasil penelitian menggunakan Mikroorganisme Lokal (MOL) Tape sebagai aktifator dalam proses pengomposan sampah organik adalah waktu terbentuknya kompos. Data waktu pengomposan sampah organik pada kelompok kontrol dan kelompok perlakuan dengan menggunakan aktifator mikroorganisme lokal (MOL) variasi dosis $10 \mathrm{ml}, 15 \mathrm{ml}, 20$ $\mathrm{ml}$, dan $25 \mathrm{ml}$.

Tabel 1 menunjukkan bahwa rerata lama waktu pengomposan pada kelompok perlakuan dengan penambahan aktifator mikroorganisme lokal (MOL) $25 \mathrm{ml}$ lama waktu terbentuknya kompos adalah 11,6 hari dengan $p$ value $0,000<0,05$, yang berarti ada pengaruh antara penambahan aktivator mikroorganisme lokal (MOL) $25 \mathrm{ml}$ terhadap lama waktu terbentuknya kompos.

Tabel 1. Hasil Uji One Way Anova Lama Waktu (hari) Pengomposan Sampah Organik Kelompok Perlakuan dan kontrol

\begin{tabular}{ccccc}
\hline $\begin{array}{c}\text { Variabel } \\
\text { Perlakuan }\end{array}$ & Mean & SD & $95 \% \mathrm{CI}$ & P value \\
\hline Kontrol & 31,5 & 1,732 & $28,74-34,26$ & \\
MOL $10 \mathrm{ml}$ & 24 & 2 & $19,03-28,97$ & \\
MOL $15 \mathrm{ml}$ & 18,6 & 1,155 & $15,80-21,54$ & 0,00 \\
MOL $20 \mathrm{ml}$ & 15 & 1 & $12,52-17,48$ & \\
MOL $25 \mathrm{ml}$ & 11,6 & 1,528 & $7,87-15,46$ & \\
\hline
\end{tabular}

Berdasarkan uji LSD selisih terkecil lama waktu pembentukan kompos sampah organik terdapat pada perlakuan $20 \mathrm{ml}$ dan $25 \mathrm{ml}$ yaitu 3,33 . Sedangkan selisih terbesar lama waktu pembentukan kompos sampah organik terdapat pada perlakuaan $25 \mathrm{ml}$ dan kontrol yaitu 19,833. Dari selisih tersebut didapat $\mathrm{p}$ value pada perlakuan $20 \mathrm{ml}$ dan 25 $\mathrm{ml}$ yaitu 0,023 dan untuk perlakuan $25 \mathrm{ml}$ dan kontrol yaitu $0,000<0,05$, ini menyatakan bahwa ada perbedaan yang bermakna pada setiap kelompok perlakuan tersebut dan kelompok yang paling efektif terdapat pada perlakuan dengan dosis $25 \mathrm{ml}$ 
Tabel 2. Hasil Uji LSD Perbedaan Lama Waktu (Hari), pengomposan Denga Menggunakan Aktifator Mikroorganisme Lokal (MOL) Dengan Variasi Dosis $10 \mathrm{ml}, 15 \mathrm{ml}, 20 \mathrm{ml}$, dan $25 \mathrm{ml}$

\begin{tabular}{cccc}
\hline \multirow{2}{*}{ Perlakuan } & $\begin{array}{c}\text { rerata beda } \\
\text { (Hari) }\end{array}$ & $\rho$ value \\
\hline \multirow{3}{*}{ Kontrol } & $10 \mathrm{ml}$ & 7,500 & 0,000 \\
& $15 \mathrm{ml}$ & 12,833 & 0,000 \\
& $20 \mathrm{ml}$ & 16,500 & 0,000 \\
& $25 \mathrm{ml}$ & 19,833 & 0,000 \\
\hline \multirow{2}{*}{$10 \mathrm{ml}$} & $15 \mathrm{ml}$ & 5,33 & 0,001 \\
& $20 \mathrm{ml}$ & 9,000 & 0,000 \\
& $25 \mathrm{ml}$ & 12,33 & 0,000 \\
\hline \multirow{2}{*}{$15 \mathrm{ml}$} & $20 \mathrm{ml}$ & 3,667 & 0,014 \\
& $25 \mathrm{ml}$ & 7,000 & 0,000 \\
\hline $20 \mathrm{ml}$ & $25 \mathrm{ml}$ & 3,333 & 0,023 \\
\hline
\end{tabular}

Hasil analisis uji LSD untuk mengetahui perbedaan dari keempat perlakuan penambahan aktifator dosis $10 \mathrm{ml}, 15 \mathrm{ml}, 20$ ml, dan $25 \mathrm{ml}$ disajikan pada Tabel 2.

Rerata lama waktu terbentuknya kompos sampah organik dengan menggunakan aktivator mikroorganisme lokal (MOL) 10 $\mathrm{ml}, 15 \mathrm{ml}, 20 \mathrm{ml}$, dan $25 \mathrm{ml}$ disajikan pada grafik berikut ini :

\section{Grafik 1}

Rerata Waktu Pengomnosan Samnah

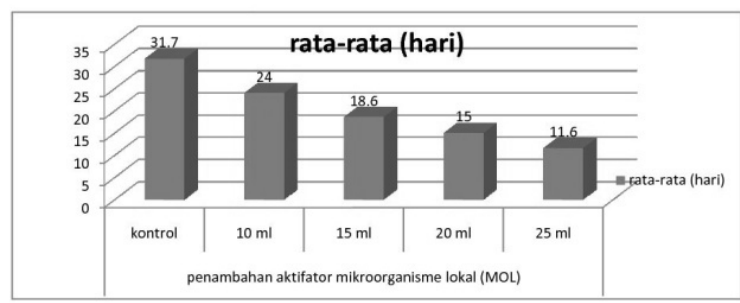

\section{PEMBAHSAN}

Berdasarkan penelitian efektifitas penambahan aktifator Mikroorganisme Lokal Tape (MOL) terhadap lama waktu terbentuknya kompos sampah organik yang dapat dilihat pada Grafik 1 diperoleh hasil bahwa rerata lama waktu terbentuknya kompos sampah organik pada kelompok perlakuan dengan penambahan aktifator Mikroorganisme Lokal (MOL) $25 \mathrm{ml}$ lebih cepat dengan rerata lama waktu pengomposan selama 11,6 hari dengan $p$ value 0,000. Penambahan aktifator Mikroorganisme Lokal (MOL) Tape kedalam bahan kompos dapat mempengaruhi waktu pengomposan, karena larutan MOL mengandung unsur hara makro dan mikro dan juga mengandung bakteri yang berpotensi sebagai perombak bahan organik, perangsang pertumbuhan dan sebagai agens pengendali hama dan penyakit tanaman.
Pemilihan bahan dasar pembuatan aktifator MOL yang berupa tape singkong, dan terasi, karena bahan-bahan tersebut mudah didapatkan di pasar tradisional dan apabila digunakan sebagai bahan pembuat aktifator kompos maka akan aman bagi tanah. Selain itu, mikroorganisme yang terdapat dalam buah-buahan mempunyai fungsi dalam hal pengomposan yaitu sebagai dekomposer sampah organik sementara terasi sebagai penyedia protein bagi mikroba pengomposan.

Penggunaan tape singkong dan terasi sebagai bahan dasar membuat aktifator terlebih dahulu difermentasi dalam $1200 \mathrm{ml}$ air bersih dan gula sebanyak 5 gram selama 5 hari. Gula merupakan bahan baku energi paling banyak digunakan oleh mikroorganisme pada proses dekomposisi sampah organik. Hasil fermentasi tape singkong berwarna kuning dan yang paling khas adalah berbau alkohol.

Ditinjau dari keadaan tersebut terbukti bahwa dengan penambahan aktifator Mikroorganisme Lokal (MOL) dapat mempercepat proses pengomposan khususnya pada kelompok perlakuan variasi dosis 25 $\mathrm{ml}$ dengan lama waktu pengomposan 11,6 hari dibandingkan kontrol dan kelompok perlakuan lainnya yakni penggunaan MOL $10 \mathrm{ml}, 15 \mathrm{ml}$, dan $20 \mathrm{ml}$, karena didalam tape terdapat bakteri kapang dan khamir. Dengan demikian semakin banyak mikroorganisme yang ada dalam bahan kompos maka akan semakin cepat dalam memproduksi sampah organik, sehingga akan mempersingkat waktu pengomposan sampah organik.

Hasil Uji One Way Anova berdasarkan Tabel 2 bahwa adanya perbedaan lama waktu pengomposan dari setiap perlakuan dilihat dari rerata waktu pengomposan pada kelompok perlakuan dengan penambahan MOL $25 \mathrm{ml}$ dengan rerata lama waktu pengomposan adalah 11,6 hari dengan $\mathrm{p}$ value 0,000 dibawah 0,05 ini menyatakan bahwa ada perbedaan yang bermakna dibandingkan proses pengomposan secara alami. Penambahan aktifator Mikroorganisme Kokal (MOL) $25 \mathrm{ml}$ lebih efektif da- 
lam mempercepat pengomposan karena mikroorganisme yang terdapat di dalam dosis $25 \mathrm{ml}$ lebih banyak sehingga proses perombakan sampah organik lebih cepat terbentuk menjadi kompos. Hal ini sesuai dengan pendapat Soeryoko (2011) yang menyatakan bahwa, semakin banyak mikroorganisme yang terkandung di dalam bahan kompos maka proses pengomposan akan lebih cepat terjadi.

Penentuan waktu pengomposan sampah organik didasarkan pada parameter pengomposan yaitu bau, warna dan berat akhir kompos. Parameter pengomposan merupakan faktor yang sangat penting untuk menentukan kompos sudah matang atau belum, sehingga harus terpenuhi sesuai dengan kriterianya. Pengukuran parameter pengomposan dilakukan setiap tiga hari sekali. Kriteria kompos matang adalah volume kompos 1/3 dari berat awal, warna hitam kecoklatan dan berbau seperti tanah. Bila kriteria kompos matang sudah terpenuhi semua, maka dapat digunakan untuk menentukan waktu mulainya kompos matang. Waktu mulainya kompos matang dapat dilihat pada lampiran data hasil pengukuran dan pengamatan yang dicetak tebal.

Keadaan awal bahan kompos secara fisik berbentuk potongan-potongan kecil, berbau seperti sampah dan berwarna hijau. Keadaan ini akan mengalami perubahan selama proses pengomposan berlangsung yakni yang tadinya hanya berupa potongan kecil maka dengan adanya proses dekomposisi dari bakteri pembusuk bahan kompos berangsur-angsur akan hancur, begitu pula dengan bau dan warna kompos juga mengalami perubahan seiring dengan perubahan bentuk fisik yaitu bahan kompos telah berbau menyengat dan berwarna hitam kecoklatan pada hari ke 12 sedangkan warna berubah dari warna hijau, hitam kecokelatan dan akhirnya berwarna seperti tanah terjadi pada hari ke 8 . Keadaan ini menunjukkan bahwa mikroorganisme yang ada telah mendekomposisi bahan kompos, tetapi mikroorganisme pada kelompok kontrol berjalan lambat dalam mendekomposisi bahan kompos bila dibandingkan dengan kelompok perlakuan yang menggunakan aktifator untuk mempercepat pengomposan.

Perubahan bentuk fisik seperti, bau dan warna akan terjadi selama proses pengomposan berjalan secara bertahap. Bahan kompos yang telah berbau menyengat kemudian timbul bau busuk dan mengalami pematangan. Keadaan ini akan disertai dengan bentuk fisik bahan kompos sedikit demi sedikit menjadi hancur dan terjadi perubahan warna dari hijau kecoklatan menjadi cokelat. Kompos yang telah matang kemudian dikeringkan dibawah sinar matahari dengan tujuan agar memperoleh ukuran kompos yang sesuai, memisahkan bahan yang belum terkomposkan secara sempurna dan mengendalikan mutu kompos. Kualitas kompos dapat diketahui dengan pemeriksaan $\mathrm{C} / \mathrm{N}$ rasio kompos matang sehingga dapat diketahui kualitas kompos mana yang lebih baik, tetapi dalam penelitian ini belum dapat diketahui kualitas mana yang lebih baik, namun hasil penelitian ini sudah dapat memberikan informasi tentang penggunaan aktifator Mikroorganisme Lokal (MOL) dengan dosis $25 \mathrm{ml} / 2 \mathrm{~kg}$ sampah organik yang lebih cepat waktu pengomposannya dibandingkan dosis aktifator $10 \mathrm{ml}, 15 \mathrm{ml}$, dan $20 \mathrm{ml}$.

Menurut Samekto (2006) proses pematangan bahan kompos akan berlangsung selama 14 hari. Pada tahap akhir pengomposan, bahan kompos akan berbau seperti tanah dengan bentuk fisik menjadi hancur dan berwarna cokelat kehitaman. Volume kompos pada semua komposter tidak sama, karena jumlah dosis aktifator yang digunakan berbeda dari masing-masing kelompok eksperimen. Pengukuran volume kompos dilakukan pada tahap akhir pengomposan dengan cara ditimbang.

Hasil penelitian ini secara keseluruhan dapat dikatakan bahwa pengomposan menggunakan aktifator Mikroorganisme Lokal (MOL) buah-buahan sebanyak $25 \mathrm{ml}$ lebih efektif dibandingkan kelompok kontrol dan kelompok perlakuan lainnya. Aabila dibandingkan penelitian terdahulu yang dilakukan oleh Driyanto, (2003) Pengaruh penambahan aktivator fix-up plus terhadap lama 
waktu terbentuknya pengomposan sampah organik. Dengan hasil penelitian yang efektif adalah $6 \mathrm{ml}$ dengan lama waktu pengomposan 20 hari sedangkan pada penelitian ini dosis yang efektif dalam pengomposan sampah organik adalah $25 \mathrm{ml}$ dengan lama waktu pengomposan selama 11, 6 hari.

\section{KESIMPULAN}

Berdasarkan hasil penelitian dapat disimpulkan bahwa : Rerata berat kompos yang terbentuk dari kelompok perlakuan terbanyak yaitu dengan menggunakan dosis aktifator MOL $25 \mathrm{ml}$ dengan berat kompos yang dihasilkan 616 gram. Sedangkan untuk dosis aktifator MOL $20 \mathrm{ml}$ berat kompos yang dihasilkan 603 gram, $15 \mathrm{ml}$ sebanyak 602 gram, dan dosis $10 \mathrm{ml}$ sebanyak 480 gram. Pengomposan dengan penambahan dosis aktifator MOL $10 \mathrm{ml}$ membutuhkan lama waktu terbentuknya kompos rerata selama 24 hari. Pengomposan dengan pe-

\section{DAFTAR RUJUKAN}

Blum, 2007. Faktor-Faktor Yang Mempe-ngaruhi Derajat Kesehatan Manu-sia. Diakses dari http://www. derajatkesehatan.com. Pada tanggal 12 Februari 2013.

Indriyani, H. Yovita. 2001. Membuat kompos Secara Kilat. Jakarta : Penebar Swadaya.

Kusnadi, 2003. Manfaat Mikroorganisme Lokal. Diakses dari http://www. manfaatmikroorganisme-lokal. com/articles/32/.tanggal 20 Dese mber 2012. nambahan dosis aktifator MOL $15 \mathrm{ml}$ membutuhkan lama waktu terbentuknya kompos rerata selama 18,6 hari. Pengomposan dengan penambahan dosis aktifator MOL $20 \mathrm{ml}$ membutuhkan lama waktu terbentuknya kompos rerata selama 15 hari. Pengomposan dengan pe-nambahan dosis aktifator MOL $25 \mathrm{ml}$ membutuhkan lama waktu terbentuknya kompos rerata selama 11,6 hari. Penambahan dosis aktifator mikroorganisme lokal (MOL) sebanyak 25 $\mathrm{ml}$ lebih efektif dibandingkan penggunaan variasi dosis aktifator $10 \mathrm{ml}, 15 \mathrm{ml}$, dan 20 $\mathrm{ml}$ dalam mempercepat waktu pengomposan sampah organik.

Diharapkan masyarakat/petani, dapat memanfaatkan tape dan terasi sebagai bahan untuk membuat aktifator dalam proses mempercepat pengomposan sampah organik dengan dosis $25 \mathrm{ml} / 2 \mathrm{~kg}$ sampah organik agar mendapatkan pupuk dengan cepat.

Mualim, 2013. Buku pedoman penulisan karya tulis ilmiah jurusan kesehatan lingkungan Poltekkes Kemenkes. Bengkulu : jurusan kesling.

Samekto. 2006. Pupuk Kompos. Klaten : PT. Intan Sejati

Wardhani, 2007. Sumber Sampah Dan MacamMacam Jenis Sampah. Yogyakarta: Fitramaya 